\title{
ERRATUM
}

\section{Erratum to: A Review of Biologic Therapies Targeting IL-23 and IL-17 for Use in Moderate-to-Severe Plaque Psoriasis}

\author{
Molly Campa $\cdot$ Bobbak Mansouri · Richard B. Warren · Alan Menter (D)
}

To view enhanced content go to www.dermtherapy-open.com

Published online: March 30, 2016

(C) The Author(s) 2016. This article is published with open access at Springerlink.com

Erratum to: Dermatol Ther (Heidelb) (2016) 6:1-12

DOI 10.1007/s13555-015-0092-3

In the original publication, the third author's name was incorrectly published as Richard Warren. The correct name should read as "Richard B. Warren".

Open Access. This article is distributed under the terms of the Creative Commons AttributionNonCommercial 4.0 International License (http://creativecommons.org/licenses/by-nc/4. $0 /$ ), which permits any noncommercial use, distribution, and reproduction in any medium, provided you give appropriate credit to the original author(s) and the source, provide a link to the Creative Commons license, and indicate if changes were made.

The online version of the original article can be found under doi:10.1007/s13555-015-0092-3.

M. Campa · A. Menter $(\bowtie)$

Division of Dermatology, Baylor University Medical

Center, Dallas, TX, USA

e-mail: amderm@gmail.com

B. Mansouri

Department of Dermatology, Baylor Scott and

White Medical Center, Temple, TX, USA

R. B. Warren

University of Manchester, Manchester, UK 